http://dx.doi.org/10.18778/1509-877X.2018.02.04

\title{
ZNACZENIE KONCEPCJI SUBSTANCE W SYSTEMACH PODATKOWYCH KANADY i AUSTRAliI
}

\begin{abstract}
Streszczenie. Problematyka artykułu koncentruje się wokół zagadnienia treści ekonomicznej (substance) i jej znaczenia w systemie podatkowym. W szczególności celem artykułu jest zbadanie, w jaki sposób koncepcja substance jest wykorzystywana w systemach podatkowych Kanady i Australii. W krajach tych nie przyjęły się tzw. sądowe doktryny orzecznicze przeciwko unikaniu opodatkowania, tak charakterystyczne zwłaszcza dla Stanów Zjednoczonych. Pomimo to zarówno w Kanadzie, jak i w Australii element rzeczywistej treści ekonomicznej działań podatników jest uwzględniany w sposób pośredni, w ramach obowiązujących w tych krajach klauzul ogólnych przeciwko unikaniu opodatkowania.
\end{abstract}

Słowa kluczowe: unikanie opodatkowania, treść ekonomiczna, klauzula przeciwko unikaniu opodatkowania

\section{WPROWADZENIE}

Współcześnie w piśmiennictwie często zwraca się uwagę, że wywiązywanie się przez państwo ze swoich funkcji wymaga zapewnienia odpowiednich źródeł finansowania, w tym dochodów pochodzących z podatków. Biorąc pod uwagę powyższe, coraz istotniejsze staje się zabezpieczenie stabilnych wypływów podatkowych i skuteczne przeciwstawianie się ich uszczuplaniu w wyniku unikania opodatkowania. W różnych systemach podatkowych wykształciły się rozmaite sposoby przeciwdziałania

* Doktor nauk prawnych, radca prawny i doradca podatkowy, manager w KPMG Tax M. Michna sp.k., e-mail: asiarusek@poczta.onet.pl 
wspomnianemu negatywnemu zjawisku; w niektórych krajach, np. w Stanach Zjednoczonych, główny ciężar spoczywa na sędziach i wykształconych przez nich tzw. doktrynach orzeczniczych (amerykańskie doktryny substance over form, economic substance, business purpose itp.). Inne kraje polegają w tym zakresie na regulacjach ustawowych, w tym zwłaszcza na tzw. klauzulach ogólnych przeciwko unikaniu opodatkowania. Niezależnie jednak od obranej przez dane państwo strategii w zakresie zwalczania unikania opodatkowania istotnego znaczenia przy dokonywaniu ocen działań podejmowanych przez podatników nabiera rzeczywisty charakter tych działań, ich ekonomiczna/gospodarcza istota (ang. substance). Celem niniejszego artykułu jest zbadanie, w jaki sposób koncepcja substance jest wykorzystywana w systemach podatkowych Kanady i Australii.

\section{Pojęcie substance a orzecznictwo kanadyjskiego SĄDU NAJWYŻSZEGO W SPRAWACH PODATKOWYCH}

W Kanadzie nie przyjęły się - tak charakterystyczne chociażby dla Stanów Zjednoczonych - sądowe doktryny orzecznicze wykorzystywane w celu zwalczania unikania opodatkowania ${ }^{1}$. W literaturze wskazuje się, że powodem takiego stanu rzeczy było powszechnie manifestowane przez kanadyjskie sądy przekonanie, że szczególnie w sprawach podatkowych konieczne jest przestrzeganie zasady praworządności (ang. rule of law). Przejawem tego podejścia była obserwowalna w wydawanych orzeczeniach skłonność sądów do interpretacji przepisów podatkowych na korzyść podatników zamiast na korzyść budżetu, naleganie na istnienie prawa podatników do organizacji własnych spraw w sposób minimalizujący lub unikający obciążeń podatkowych oraz preferowanie rozwiązań, w których istniejące luki w przepisach podatkowych są domykane nie przez orzecznictwo, ale w formie zmian ustawodawczych ${ }^{2}$. Poszukując źródła wspomnianego stanowiska, w literaturze wskazuje się, że historycznie dominującą cechą kanadyjskiego orzecznictwa w sprawach podatkowych była praktycznie jednomyślność odnośnie do tego, że podatek nie może zostać nałożony w braku jasnego, jednoznacznego upoważnienia ustawowego. Jak

1 Por. L. Philipps, The Supreme Court of Canada's Tax Jurisprudence: What's wrong with the rule of law, „Canadian Bar Review” 2000, vol. 79, s. 124.

2 Ibidem. 
twierdziły sądy, dopuszczenie innej sytuacji stanowiłoby bowiem poważne zagrożenie właśnie dla praworządności ${ }^{3}$.

W kanadyjskim orzecznictwie w sprawach podatkowych nie przyjęła się zwłaszcza doktryna economic substance ${ }^{4}$; pojęcie treści jest zasadniczo utożsamiane $\mathrm{z}$ treścią prawną, jako przeciwstawienie treści ekonomicznej. Zgodnie ze stanowiskiem sędziego D. Bowmana - wyrażonym przykładowo w wyroku (z 1995 r.) w sprawie Continental Bank of Canada - „treść" oznacza „treść prawną”, tj. treść wynikającą z praw i obowiązków stron, ustaloną zgodnie ze zwykłymi zasadami prawnymi ${ }^{5}$.

W literaturze wskazuje się na silne zakorzenienie w kanadyjskim prawie podatkowym zasady - zwanej zasadą Duke’a z Westminsteru (Duke of Westminster principle) - zgodnie z którą każdy podatnik jest upoważniony do prowadzenia swoich spraw w sposób umożliwiający minimalizację obciążeń podatkowych. Zasada ta wywodzi się z idei ścisłego, literalnego podejścia do wykładni przepisów prawa, która przetrwała w odniesieniu do ustaw podatkowych na długo po tym, jak została odrzucona na gruncie innych gałęzi prawa. Zasada Duke’a z Westminsteru jest przy tym w kanadyjskim prawie podatkowym tak ugruntowana, że jest niezmiennie stosowana przez sądy bez jakiejkolwiek głębszej analizy odnośnie do źródeł jej pochodzenia czy jej aktualności ${ }^{6}$.

Kanadyjski Sąd Najwyższy potwierdził zastosowanie zasady Duke’a z Westminsteru w wielu sprawach, zwłaszcza w serii zapadłych pod koniec lat dziewięćdziesiątych ubiegłego wieku orzeczeń dotyczących przypadków

3 Ibidem, s. 125.

${ }^{4}$ Przykładowo, J.S. Wilkie zwraca uwagę, że do kanadyjskiego prawa podatkowego nie została inkorporowana doktryna economic substance, a moralność nie jest traktowana jako wyznacznik przy stosowaniu ustawy o podatku dochodowym. Konsekwentnie kanadyjski Sąd Najwyższy (SN) odrzucił możliwość opodatkowania opartego zasadniczo na „realiach ekonomicznych” zachowania podatnika. Przeciwnie, sąd generalnie opowiada się za respektowaniem dla celów podatkowych relacji prawnych nawiązanych przez podatnika. Por. J.S. Wilkie, Canada: Substance in International Taxation, „International Transfer Pricing Journal” wrzesień-październik 2014, s. 362.

5 Por. B.J. Arnold, J. Li, Justice Bowman on Substance over Form, „Canadian Tax Journal" 2010, vol. 58, s. 133.

${ }^{6}$ Ibidem, s. 128. Jak pisze B. Brzeziński, „podejście kanadyjskich sądów do problematyki wykładni prawa podatkowego, a zwłaszcza w dziedzinie unikania opodatkowania, jest zdecydowanie bardziej podobne do tego, które można zaobserwować w Zjednoczonym Królestwie, niż w bliższych geograficznie Stanach Zjednoczonych. Charakteryzuje je wyraźny prymat wykładni literalnej przepisów prawa podatkowego" (B. Brzeziński, Anglosaskie doktryny orzecznicze dotyczace unikania opodatkowania, Toruń 1996, s. 86). 
rażącego planowania podatkowego. Przykładowo, w sprawie Shell Canada Ltd. (z 1999 r.) SN nie zanegował wprawdzie konieczności brania pod uwagę ekonomicznych realiów danej transakcji, stwierdził jednak, że realia te nie mogą stanowić podstawy do przekwalifikowania powstałych w dobrej wierze stosunków prawnych ( $\mathrm{z}$ wyjątkiem sytuacji, gdy forma prawna użyta przez podatnika nie odzwierciedla rzeczywistych skutków prawnych), ani też do modyfikowania sposobu zastosowania niedwuznacznych przepisów ustawowych ${ }^{7}$. Stan faktyczny rozstrzygany przez sąd dotyczył możliwości odliczenia przez spółkę Shell pełnej kwoty odsetek zapłaconych z tytułu pożyczki w dolarach nowozelandzkich. W celu obniżenia całkowitych kosztów związanych z zaciągnięciem pożyczki (100 mln USD) z przeznaczeniem na ogólną działalność gospodarczą, spółka Shell wdrożyła popularny schemat planowania podatkowego bazujący na zależności pomiędzy wysokością stóp procentowych i kursami walut (odsetki wahają się odwrotnie proporcjonalnie do siły waluty, w której denominowane jest zadłużenie). Dzięki zastosowanemu scenariuszowi wysokość odsetek - zaliczanych przez Shell do kosztów uzyskania przychodów przez czas trwania pożyczki - została podniesiona z 9,1\% (rynkowa stopa oprocentowania dla zadłużenia w USD) do 15,4\% (rynkowa stopa oprocentowania dla zadłużenia w dolarach nowozelandzkich). Jednocześnie, w związku z towarzyszącymi przeprowadzonej operacji dodatkowymi transakcjami finansowymi (emisja obligacji, zawarcie umów hedgingowych), Shell wygenerował zysk kapitałowy, który jednak mógł zostać rozliczony z posiadanymi stratami $\mathrm{z}$ lat ubiegłych. Kanadyjska administracja podatkowa zakwestionowała możliwość odliczenia przez Shell odsetek w części przewyższającej stopy procentowe obowiązujące dla pożyczek w USD, tj. nadwyżki ponad 9,1\% . Stanowisko administracji skarbowej zostało potwierdzone przez Federalny Sąd Apelacyjny, jednakże ostatecznie Sąd Najwyższy rozstrzygnął sprawę na korzyść podatnika.

W literaturze wskazuje się, że preferowanie przez kanadyjskie sądy ścisłej, literalnej wykładni przepisów podatkowych stanowi wyraz klasycznego, liberalnego pojmowania przez te sądy idei sprawiedliwości społecznej ${ }^{9}$. Właśnie tradycyjnym doktrynom podatkowym towarzyszy bowiem przeświadczenie, że podatki z samej swej natury stanowią

7 Por. B.J. Arnold, J. Li, Justice Bowman..., s. 129.

8 Por. A. Duggan, J.S. Ziegel, J. Girgis, 449 - Shell Canada Limited: A New Taste of the Economic Substance over Form, „Canadian Business Law Journal” 1998, vol. 30, s. 2.

9 Por. L. Philipps, The Supreme Court of Canada's Tax Jurisprudence..., s. 128. 
„podejrzany” przejaw aktywności ze strony państwa. Z zasady podatki są zatem traktowane jako naruszenie wolności. W konsekwencji w orzecznictwie w sprawach podatkowych jako najwyższa wartość stawiana jest klasyczna liberalna idea wolności negatywnej (wolności „od”, ang. liberty from / freedom from). Współcześnie liberalizm rozwinął się jednak w taki sposób, by oprócz wolności negatywnej (wolności „od”) uwzględniać także ideę wolności pozytywnej (wolności „do”, ang. freedom to). Wskazuje się bowiem, że aby jednostka rzeczywiście miała możliwość podejmowania decyzji i realizowania własnej koncepcji dobrego życia, konieczne jest zapewnienie jej pewnego minimalnego poziomu materialnego, co często wymaga wsparcia ze strony państwa ${ }^{10}$. Zamiast być postrzeganym jako zagrożenie dla wolności, rozbudowane, silne państwo staje się więc najważniejsze dla promocji wolności. Wspomniana funkcja państwa nie może jednak być realizowana bez zdolności tego państwa do poboru i redystrybucji podatku ${ }^{11}$. W literaturze wskazuje się, że w tym kontekście postrzeganie państwa oraz podatków jako zagrożenia dla indywidualnej wolności musi być uznane za anachroniczne ${ }^{12}$.

Początki krytycznego - jak mogłoby się wydawać - podejścia samego Sądu Najwyższego Kanady do ścisłej wykładni w prawie podatkowym zazwyczaj datuje się na rok 1984 i orzeczenie w sprawie Stubart ${ }^{13}$. Rozstrzygany stan faktyczny obejmował sytuację, w której pomiędzy spółkami powiązanymi były realizowane transakcje służące transferowi dochodu z pierwszej z nich - zyskownej do drugiej - przynoszącej straty. W analizowanej sprawie przyznano, że transakcje były umotywowane względami czysto podatkowymi; chodziło o to, by zyski generowane przez jedną

10 Ibidem.

11 Ibidem, s. 129.

12 Ibidem, s. 130.

13 Ibidem, s. 134. Także B. Alarie i D.G. Duff zwracają uwagę, że Sąd Najwyższy Kanady formalnie odrzucił ścisłą wykładnię przepisów podatkowych w sprawie Stubart Investments Ltd. v. The Queen, potwierdzając jednocześnie tzw. nowoczesną zasadę (ang. modern rule) profesora Elmera Driedgera, zgodnie z którą słowa aktu prawnego należy czytać w ich zwykłym znaczeniu, przy uwzględnieniu szerszego kontekstu, struktury i celu danej ustawy oraz intencji parlamentu. Jednocześnie jednak, charakteryzując transakcję i stosunki między stronami, Sąd nie był chętny do odrzucenia tradycyjnego podejścia, odmawiając zastosowania orzeczniczego testu business purpose i potwierdzając prawo podatników do wykorzystania korzystnych przepisów podatkowych, jeżeli nie było to wprost zabronione przez ustawę. Por. B. Alarie, D.G. Duff, The legacy of UK tax concepts in Canadian income tax law, „British Tax Review” 2008, no. 3, s. 244. 
spółkę mogły być rozliczone ze stratami generowanymi przez drugą, co obniżyłoby obciążenie podatkowe grupy jako całości. Powyższy cel miał być osiągnięty poprzez przeniesienie na spółkę generującą straty całego przedsiębiorstwa / działalności gospodarczej spółki zyskownej, przy czym wspomniana działalność gospodarcza miała nadal być prowadzona przez spółkę zyskowną w charakterze agenta. W konsekwencji zyskowna spółka miała kontynuować swoją działalność gospodarczą na dotychczasowych zasadach, $\mathrm{z}$ tym że zyski $\mathrm{z}$ tej działalności miały być przypisywane na rachunek spółki generującej straty ${ }^{14}$.

Rozstrzygając sprawę Stubart, sędzia W. Estey wyraził pogląd, że przepisy prawa podatkowego powinny być wykładane w analogiczny sposób jak przepisy innych gałęzi prawa, zgodnie z nowoczesną zasadą, w myśl której słowa aktu prawnego należy czytać w ich zwykłym znaczeniu, przy uwzględnieniu szerszego kontekstu, struktury i celu danej ustawy oraz intencji parlamentu. Pomimo powyższego - rewolucyjnego, jak mogłoby się wydawać - stwierdzenia, w nowych wskazówkach interpretacyjnych sędziego Esteya nadal znać było silne przywiązanie do tradycyjnej literalnej wykładni ustaw podatkowych. Znalazło to potwierdzenie w sposobie, w jaki wspomniane wskazówki zostały zastosowane przez sam Sąd Najwyższy w sprawie Stubart. Rozstrzygając sprawę na korzyść podatnika, sędzia Estey podkreślił mianowicie brak istnienia jakichkolwiek wyraźnych przepisów ustawowych zakazujących spółce przynoszącej straty nabywania nowych źródeł dochodu w drodze nierynkowych transakcji mających na celu wykorzystanie strat $\mathrm{z}$ lat ubiegłych. Sąd zasadniczo zignorował zatem swoje własne zalecenia co do konieczności uwzględniania kontekstu i celu przepisów wykorzystywanych przez podatnika. Sędzia Estey skoncentrował się wąsko na literalnym brzmieniu regulacji dotyczących rozliczania strat, interpretując je ściśle - a więc na korzyść podatnika - i pomijając okoliczność, że generalnym zamysłem całego aktu prawnego było przeciwdziałanie konsolidacji zysków i strat podmiotów powiązanych ${ }^{15}$. Co więcej, w sprawie Stubart sąd bezpośrednio i zdecydowanie odrzucił argumentację organów skarbowych opartą na teście celu gospodarczego, umożliwiającym unieważnienie transakcji motywowanych względami czysto podatkowymi ${ }^{16}$.

14 Por. L. Philipps, The Supreme Court of Canada's Tax Jurisprudence..., s. 136.

15 Ibidem, s. 137.

${ }^{16}$ Ibidem. Zob. także B. Brzeziński, Anglosaskie doktryny orzecznicze..., s. 90, oraz J. Freedman, Converging Tracks? Recent Developments in Canadian and UK Approaches to Tax Avoidance, „Canadian Tax Journal” 2005, vol. 53, no. 4, s. 1039. 
3. KanADYJSKa KLAUZULA OgÓLNA PRZECIWKO UNIKANIU OPODATKOWANIA

W literaturze podnosi się, że właśnie dostrzeżona nieskuteczność wskazówek ze sprawy Stubart w walce $\mathrm{z}$ unikaniem opodatkowania, w połączeniu z wyrażaną przez Sąd Najwyższy aprobatą dla planowania podatkowego jako podstawowego prawa obywateli, legły u podstaw wprowadzenia w 1988 r. w Kanadzie generalnej klauzuli przeciwko unikaniu opodatkowania ${ }^{17}$.

Kanadyjska klauzula przeciwko unikaniu opodatkowania (General Anti-Avoidance Rule - GAAR) zawarta jest w sekcji 245 ustawy o podatku dochodowym (ang. Income Tax Act - ITA). Jak stwierdza się w literaturze, „sens normatywny klauzuli sprowadza się do tego, że jeśli transakcja została dokonana w celu uniknięcia podatku (an avoidance transaction), podatnikowi odmawia się płynących z niej bezpośrednio lub pośrednio korzyści podatkowych i konsekwencje podatkowe zaistniałego stanu rzeczy ustala się w „rozsądnym”, stosownym, uzasadnionym w danych okolicznościach kształcie"18. Pojęcie transakcji, która została dokonana w celu uniknięcia podatku, zostało zdefiniowane w podsekcji 245(3) ITA i obejmuje transakcję (lub fragment kilku transakcji), która - gdyby nie zastosowanie GAAR - skutkowałaby bezpośrednio lub pośrednio uzyskaniem korzyści podatkowych, z wyjątkiem sytuacji, gdy można rozsądnie/racjonalnie (reasonably) przyjąć, że transakcja została zrealizowana przede wszystkim w rzeczywistych/uzasadnionych (bona fide) ${ }^{19}$ celach, innych niż pozyskanie tych korzyści. W myśl podsekcji 245(4) ITA transakcja, która została dokonana

17 Por. L. Philipps, The Supreme Court of Canada's Tax Jurisprudence..., s. 138. Zob. także J. Li, „Economic Substance”: Drawing the line between legitimate tax minimization and abusive tax avoidance, "Canadian Tax Journal” 2006, vol. 54, no. 1, s. 36. Również A. Olesińska stwierdza, że „ostatecznym impulsem do wprowadzenia klauzuli stał się wyrok kanadyjskiego Sądu Najwyższego w sprawie Stubart Investments Ltd v. The Queen, który potwierdził prawo podatnika do aranżowania transakcji w taki sposób, by zminimalizować obciążenia podatkowe (zasada znana w orzecznictwie jako Westminster principle). Sąd w wyroku tym odrzucił stanowisko, w myśl którego warunkiem legitymizującym na płaszczyźnie podatkowej transakcję korzystną dla podatnika jest jej gospodarcza celowość (business purpose test)" (A. Olesińska, Klauzula ogólna przeciwko unikaniu opodatkowania, Toruń 2013, s. 189).

18 Por. A. Olesińska, Klauzula ogólna..., s. 190-191.

19 A. Olesińska pisze tu o powodach „zasługujących na uznanie i ochronę” (ibidem, S. 192). 
w celu uniknięcia podatku, podlega GAAR tylko w sytuacji, gdy w sposób racjonalny można przyjąć, że skutkowałaby ona - w sposób bezpośredni lub pośredni - nadużyciem konkretnych przepisów ITA lub innych wspomnianych tam przepisów podatkowych (w tym również tych regulacji traktowanych jako całość).

W literaturze wskazuje się, że rzeczywiste/uzasadnione (bona fide) cele zrealizowania danej transakcji przesądzające o niestosowaniu GAAR obejmują nie tylko cele gospodarcze (business purpose test), ale też rodzinne ${ }^{20}$. Biorąc pod uwagę użyte w podsekcji 245(3) ITA pojęcie reasonably, kwestia celu, dla którego została przeprowadzona dana transakcja, powinna być przy tym rozstrzygana na podstawie kryteriów obiektywnych. W konsekwencji decydujące znaczenie powinny mieć okoliczności dotyczące samej transakcji, a nie podatnika (jego zamiarów czy indywidualnej sytuacji) ${ }^{21}$. W literaturze zwraca się także uwagę, że przeprowadzenie danej transakcji przede wszystkim w celach gospodarczych nie może zostać wykluczone tylko ze względu na - znaczną nawet - wysokość uzyskanej korzyści podatkowej ${ }^{22}$.

Pomimo formalnego wprowadzenia klauzuli w pierwszych sprawach opartych na GAAR - Canada Trustco Mortgage Co oraz Mathew - rozstrzyganych przez Sąd Najwyższy w 2005 r., praktycznie wyeliminowana została jakakolwiek znacząca rola treści ekonomicznej dla ustalenia, czy transakcja służąca uniknięciu opodatkowania ma charakter nadużycia. Chociaż w orzeczeniach tych sąd teoretycznie odniósł się do materiałów wyjaśniających towarzyszących wprowadzeniu klauzuli, z których jasno wynika, że przepisy ustawy o podatku dochodowym mają mieć zastosowanie wyłącznie do transakcji mających rzeczywistą treść ekonomiczną, to jednak w praktyce SN odrzucił jakiekolwiek rozważania dotyczące treści ekonomicznej w sytuacji, gdy regulacje ustawowe wprost się do niej nie odnoszą ${ }^{23}$.

20 Por. J. Cassidy, „To GAAR or Not to GAAR - That is the Question”: Canadian and Australian Attempts to Combat Tax Avoidance, „Ottawa Law Review” 2005, vol. 36, no. 2, s. 297. Zob. też A. Olesińska, Klauzula ogólna..., s. 195: „wystarczy, jeśli główny cel transakcji to bona fide purpose inny niż chęć osiągnięcia korzyści podatkowej. Nie musi to - choć może - być cel gospodarczy; obok niego także względy rodzinne, finansowe (lecz niepodatkowe) stanowią wystarczające usprawiedliwienie dla zawarcia transakcji, przynoszącej - przy okazji - korzyści podatkowe”.

${ }^{21}$ Por. J. Cassidy, „To GAAR or Not to GAAR - That is the Question”..., s. 290.

22 Ibidem.

${ }^{23}$ Por. B.J. Arnold, J. Li, Justice Bowman..., s. 130. W szczególności J. Li zwraca uwagę, że materiały wyjaśniające towarzyszące wprowadzeniu klauzuli odnoszą się do 
Podobnie jak w typowych sprawach, w których w grę wchodziło unikanie opodatkowania, stan faktyczny w sprawach Canada Trustco oraz Mathew obejmował wiele złożonych transakcji. W Canada Trustco chodziło o sprzedaż połączoną z leasingiem zwrotnym znacznych składników majątku, co miało na celu zwiększenie wysokości dostępnych odpisów z tytułu amortyzacji podatkowej. Z kolei sprawa Mathew obejmowała szereg transakcji, poprzez które niewypłacalna spółka powiernicza zmierzała do przeniesienia narosłych strat do niepowiązanych podmiotów trzecich (nabywców) przy wykorzystaniu spółki osobowej ${ }^{24}$. Pierwsza z tych spraw została przez Sąd Najwyższy rozstrzygnięta na korzyść podatnika, natomiast druga - na korzyść administracji skarbowej ${ }^{25}$. Ze względu na powyższe szczególnie sprawa Canada Trustco doczekała się w literaturze szerokiego omówienia. Analizując wspomniany wyrok, zwrócono m.in. uwagę, że pojęcie kosztu zostało tam potraktowane jako pojęcie prawne. Sąd stwierdził mianowicie, że zagadnienie treści ekonomicznej musi być analizowane z uwzględnieniem właściwej interpretacji stosownych przepisów ustawowych. W rozstrzyganej sprawie przepisy ustawy nie odwoływały się natomiast do pojęcia ryzyka ekonomicznego, lecz do pojęcia kosztu, stanowiącego dobrze wykształcone pojęcie prawne. W konsekwencji przyjęto, że niewystępowanie celu ekonomicznego czy gospodarczego transakcji jest niewystarczające dla uznania, że transakcja ma charakter nadużycia ${ }^{26}$.

Uwzględniając kanadyjski dorobek orzeczniczy, w literaturze wskazuje się, że aktualnie wielkim wyzwaniem dla tamtejszego SN jest ostateczne rozprawienie się ze spuścizną wykładni literalnej i wyznaczenie sędziom

„rzeczywistej treści ekonomicznej” (real economic substance) prawdopodobnie w celu podkreślenia, że analiza prowadzona na gruncie GAAR powinna mieć charakter ekonomiczny, tzn. powinna być prowadzona $z$ takiej samej perspektywy, jaka jest stosowana na Wall Street. W kontekście GAAR treść ekonomiczna nie obejmuje przy tym zmian w sytuacji podatnika wynikających jedynie z poczynionych oszczędności podatkowych. Por. J. Li, „Economic Substance”..., s. 43. Jak zostało stwierdzone w dokumencie kanadyjskiego Ministerstwa Finansów zatytułowanym The White Paper, celem GAAR miało być zapobieganie sztucznemu planowaniu służącemu uniknięciu opodatkowania poprzez wprowadzenie do ustawy o podatku dochodowym testu business purpose. Por. J. Cassidy, "To GAAR or Not to GAAR - That is the Question”..., s. 263.

${ }^{24}$ Por. D.G. Duff, The Supreme Court of Canada and the General Anti-Avoidance Rule: Canada Trustco and Mathew, „Bulletin for International Taxation” 2006, vol. 60, no. 54 , s. 55 .

25 Ibidem, s. 57.

${ }_{26}$ Por. J. Freedman, Converging Tracks?..., s. 1043. 
rozstrzygającym sprawy podatkowe bardziej aktywnej roli w „ulepszaniu” systemu podatkowego. Nie oznacza to konieczności rezygnacji przez Sąd Najwyższy z dotychczasowych idei wolności czy praworządności, wiele można bowiem osiągnąć tylko poprzez zastosowanie bardziej nowoczesnych definicji tych pojęć. Chodzi tu w szczególności o poszerzenie przez Sąd sposobu rozumienia idei wolności w taki sposób, aby uwzględnić rolę państwa jako promotora pozytywnej wolności obywateli, realizowanej za pośrednictwem stosowanej przez to państwo polityki podatkowej ${ }^{27}$.

\section{AustralijSkie KLAUZUle PRZeciWko UnikaniU opodatkowania}

Podobnie jak w Kanadzie, tak i w australijskim systemie podatkowym nie funkcjonuje generalna doktryna orzecznicza economic substance ${ }^{28}$. Koncepcja substance może natomiast być analizowana w kontekście klauzul - ogólnej oraz szczególnych - przeciwko unikaniu opodatkowania.

Australijska klauzula ogólna przeciwko unikaniu opodatkowania - w jej obecnym kształcie - obowiązuje od 1981 r. i jest zawarta w Części IVA ustawy o podatku dochodowym z 1936 r. (Income Tax Assessment Act - ITAA) ${ }^{29}$. Przesłanką zastosowania klauzuli jest: „osiągnięcie przez podatnika korzyści podatkowej w związku z planem (scheme) oraz ustalenie, że głównym celem uczestnika planu było umożliwienie - sobie albo komu innemu - osiągnięcia korzyści podatkowej. Kluczową rolę odgrywają zatem pojęcia planu i jego celu oraz pojęcie korzyści podatkowej”30. Stwierdzenie zaistnienia drugiej z wymienionych przesłanek, tj. celu osiągnięcia korzyści podatkowej, musi zostać ustalone na podstawie kryteriów obiektywnych $^{31}$, przy uwzględnieniu licznych okoliczności wyszczególnionych w sekcji 177D ITAA. Jedną z nich jest właśnie treść (substance) realizowanego przez podatnika planu (dokonanych czynności). Zgodnie ze wskazówkami australijskiej administracji skarbowej Część IVA ITAA

27 Por. L. Philipps, The Supreme Court of Canada's Tax Jurisprudence..., s. 131.

28 Jak stwierdza się w literaturze, Australia należy do jurysdykcji, które nigdy nie polegały na orzeczniczych doktrynach przeciwko unikaniu opodatkowania. Por. B. Kujinga, The UK General Anti Abuse Rule: Lessons for Australia?, „eJournal of Tax Research” 2016, vol. 14 , no. 3 , s. 632 .

${ }_{29}$ Por. J. Tretola, Comparing the New Zealand and Australian GAAR, „Revenue Law Journal" 2017, vol. 25, no. 1, s. 9.

30 Por. A. Olesińska, Klauzula ogólna..., s. 54.

31 Ibidem, s. 67. 
może mieć zastosowanie do sytuacji, w których rezultat podatkowy danego planu/porozumienia pozostaje w sprzeczności z jego rezultatem gospodarczym/ekonomicznym (np. do sytuacji, w których pomimo zrealizowania ekonomicznie zyskownej transakcji/przedsięwzięcia dla celów podatkowych wykazywana jest strata) $)^{32}$.

Przez pewien czas w australijskim orzecznictwie opartym na klauzuli dominowało przeświadczenie o możliwości dokonania dychotomicznego podziału transakcji na te realizujące cele gospodarcze i te mające głównie cele podatkowe. Jak stwierdził sędzia J. Hill w korzystnym dla podatnika wyroku z 1994 r. w sprawie Peabody, Część IVA ITAA tylko rzadko (jeżeli w ogóle) będzie miała zastosowanie do transakcji mających - jako całość - charakter gospodarczy, nawet jeśli niektóre elementy takich transakcji zostały dobrane w sposób umożliwiający redukcję obciążenia podatkowego ${ }^{33}$. Warto nadmienić, że wspomniany wyrok stanowił pierwsze rozstrzygnięcie australijskiego Sądu Najwyższego zapadłe na gruncie Części IVA ITAA i dotyczył wielu transakcji, za pośrednictwem których trust rodziny Peabody - posiadający 62\% udziałów w grupie spółek Pozzolanic - odkupił od drugiego wspólnika pozostałe 38\% udziałów w celu upublicznienia spółek na giełdzie, eliminując przy tym podatek od zysków kapitałowych od różnicy pomiędzy wartością emisyjną a ceną nabycia ${ }^{34}$. W późniejszym czasie powołana teza sędziego Hilla straciła jednak na aktualności. Przełomowy w tej sprawie okazał się wyrok z 1996 r. w sprawie Spotless. W rozstrzyganym stanie faktycznym chodziło o dochód spółki Spotless Services Ltd z tytułu odsetek od dokonanych inwestycji krótkoterminowych (w wysokości 2670663 AUD) rzekomo pochodzący ze źródła przychodów zlokalizowanego na Wyspach Cooka i w konsekwencji podlegający opodatkowaniu tamtejszym pięcioprocentowym podatkiem u źródła, a jednocześnie korzystający ze zwolnienia $\mathrm{z}$ australijskiego podatku dochodowego ${ }^{35}$. Broniąc się przed zastosowaniem klauzuli, podatnik przekonywał, że głównym celem jego działania nie było uzyskanie korzyści podatkowej, lecz maksymalnego zwrotu z zainwestowanych funduszy po potrąceniu wszelkich kosztów, w tym podatków. Australijski Sąd Najwyższy odrzucił jednak

32 Por. J. Tretola, Comparing..., s. 18.

33 Ibidem, s. 16.

${ }^{34}$ Por. J. Cassidy, Peabody v FCT and Part IVA, „Revenue Law Journal” 1995, vol. 5, s. $198-199$.

35 Por. J. Azzi, Spotless: A Lesson in Form and Substance but not in Substance over Form, „Revenue Law Journal” 1998, vol. 8, s. 175-176. 
powyższą argumentację, wyjaśniając, że zastosowanie Części IVA ITAA nie podlega takim ograniczeniem, i stwierdzając, że plan (scheme) może mieć cechy racjonalnej decyzji gospodarczej, a jednocześnie jego głównym celem może być uzyskanie korzyści podatkowej ${ }^{36}$. W uzasadnieniu wyroku w sprawie Spotless - cytując przy tym pogląd sędziego O.W. Holmesa z orzeczenia amerykańskiego Sądu Najwyższego z 1927 r. w sprawie Compania de Tobacos - SN zwrócił ponadto uwagę, że podatki stanowią cenę, którą płacimy za „cywilizowane społeczeństwo”. Rozwijając powyższą tezę, sąd stwierdził dalej, że jednym z elementów tego społeczeństwa są praktyki handlowe (ang. conduct of commerce), które są wspierane i chronione (ang. fostered and protected) także przez ustawy podatkowe ${ }^{37}$.

W literaturze wskazuje się, że istnieje wiele okoliczności, których wystąpienie może przemawiać za zastosowaniem do danej transakcji klauzuli ogólnej. Część wspomnianych okoliczności nawiązuje właśnie do treści (substance) dokonanych przez podatnika czynności; chodzi zwłaszcza o sytuacje, gdy:

- transakcja (lub szereg transakcji) nie generuje żadnego wyniku (zysku ani straty) z perspektywy ekonomicznej, np. gdy cały plan (scheme) ma charakter samoznoszący się;

- transakcja nie ma treści ekonomicznej i nie jest w racjonalny sposób powiązana z żadnym użytecznym celem niepodatkowym, np. w przypadku działań wewnątrzgrupowych / podejmowanych w ramach podmiotów powiązanych, które skutkują jedynie uzyskaniem określonego wyniku podatkowego ${ }^{38}$.

Rzeczywista treść ekonomiczna danej transakcji ma również znaczenie dla wyliczania korzyści podatkowej na potrzeby Części IVA ITAA. Powyższe następuje poprzez porównanie konsekwencji podatkowych rzeczywistego

${ }^{36}$ Ibidem, s. 182-183. Zob. także A. Olesińska, Klauzula ogólna..., s. 73-75: „orzecznictwo dość długo stało na stanowisku, że jeżeli transakcji można przypisać ogólny cel gospodarczy, to wyklucza to zastosowanie do niej klauzuli. Przełomowy okazał się wyrok w sprawie Spotless. Uznano w nim, że jeżeli głównym motywem przesądzającym o finansowej atrakcyjności transakcji jest jej skutek w postaci korzyści podatkowej, to klauzula ma zastosowanie, mimo iż cel finansowy jako taki jest wszak celem gospodarczym. [...] Co do zasady poglądy orzecznictwa ustabilizowały się w ten sposób, że ogólny cel biznesowy przedsięwzięcia nie uzasadnia odstąpienia od zastosowania klauzuli, jeśli części (jednej lub kilku transakcjom) z całego przedsięwzięcia może zostać przypisany - jako dominujący - cel podatkowy".

37 Por. J. Azzi, Spotless..., s. 178.

38 Por. M. D’Ascenzo, Part IVA: Post Spotless, „Journal of Australian Taxation” lipiec/ sierpień 1998, s. 11. 
stanu rzeczy ze stanem rzeczy, który wystąpiłby (lub - według rozsądnych oczekiwań - mógłby wystąpić), gdyby plan (scheme) nie był realizowany ${ }^{39}$. Zgodnie z dodaną w 2013 r. (w wyniku nowelizacji ITAA) nową sekcją $177 \mathrm{CB}$ ustalenie owego alternatywnego stanu rzeczy (założenia alternatywnego (alternative postulate)) jest możliwe na dwa sposoby. Pierwszy z nich polega na pozbawieniu skutków podatkowych określonych czynności / unieważnieniu planu (annihilation of the scheme). Drugi natomiast przewiduje możliwość rekonstrukcji (reconstruction) podatkowoprawnego stanu faktycznego, przy czym owa rekonstrukcja musi się opierać właśnie na rzeczywistej treści (substance) realizowanego przez podatnika scheme i musi uwzględniać skutki podatkowe, które zostały lub zostałyby osiągnięte. Wspomniana rekonstrukcja musi jednocześnie stanowić racjonalną alternatywę dla działań podjętych przez podatnika ${ }^{40}$.

Rozważając wreszcie koncepcję substance w kontekście zawartych w regulacjach podatkowych norm szczególnych (Special Anti-Avoidance Rules - SAARs), wskazać można na sekcję 974 ustawy o podatku dochodowym z 1997 r., regulującą podatkowe aspekty dotyczące finansowania kapitałem i długiem ${ }^{41}$. W części ogólnej tej sekcji zostało wprost stwierdzone, że dla rozstrzygnięcia, czy dana metoda/plan (scheme) finansowania stanowi finansowanie kapitałem czy finansowanie długiem, decydujące znaczenie powinna mieć treść ekonomiczna (economic substance) - istota wynikających z zastosowania danego scheme praw i obowiązków - a nie przyjęta forma prawna ${ }^{42}$.

39 Por. B. Kujinga, The UK General Anti Abuse Rule..., s. 636.

${ }^{40}$ Ibidem, s. 637-638. Autor ten zwraca uwagę, że nowelizacja ITAA była bezpośrednią odpowiedzią na wiele korzystnych dla podatników wyroków, i jednoznacznie przesądza, że - przyjęte dla potrzeby określenia korzyści podatkowej - założenie alternatywne niekoniecznie musi być tym branym pod uwagę przez podatnika. Przyjęte założenie alternatywne musi jedynie być rozsądne, biorąc pod uwagę istotę (substance) danego scheme oraz jakikolwiek cel, który zostałby osiągnięty przez podatnika. Por. ibidem, s. 638. W ten sposób wykluczona została możliwość podnoszenia przez podatnika argumentacji, że - gdyby scheme nie mógł być realizowany - nie zostałyby podjęte żadne działania.

${ }^{41}$ Sekcja ta została wprowadzona do australijskiej Income Tax Assessment Act w 2001 r. Por. Australian Government. The Board of Taxation. Review of the debt and equity tax rules. Discussion Paper, marzec 2014, s. v, http://taxboard.gov.au/files/2015/07/ Debt_Equity_Discussion_Paper.pdf (dostęp: 28.01.2018).

42 Sekcja 974-5 (1): „Test służący do rozróżnienia pomiędzy odsetkami o charakterze dłużnym i odsetkami o charakterze kapitałowym koncentruje się raczej na treści ekonomicznej niż na samej formie prawnej (por. sekcja 974-10 (2))”. Sekcja 974-10 (2): „Test, o którym mowa w sekcji (1), powinien być przeprowadzany raczej na podstawie treści 
Zarówno w Kanadzie, jak i w Australii - pomimo że są to kraje systemu common law - nie przyjęło się zwalczanie unikania opodatkowania przy wykorzystaniu (opartych na koncepcji substance) tzw. doktryn orzeczniczych. Wydaje się, że w Australii zagadnienie to w ogóle nie było przedmiotem szerszego zainteresowania orzecznictwa. Z kolei w Kanadzie sądy - w obawie przed zagrożeniem tzw. rule of law i prawa podatników do układania swoich spraw w sposób umożliwiający minimalizację obciążeń podatkowych - przez długi czas pozostawały pod silnym wpływem prymatu ścisłej, literalnej wykładni przepisów podatkowych.

Powyższe nie oznacza, że dla potrzeb rozliczeń podatkowych element rzeczywistej treści ekonomicznej działań podatników pozostaje bez znaczenia; zarówno w Kanadzie, jak i w Australii od dłuższego czasu obowiązują tzw. klauzule ogólne przeciwko unikaniu opodatkowania. Porównując przepisy kanadyjskiej sekcji 245 ITA i australijskiej Część IV ITAA, można przede wszystkim stwierdzić, że obie wspomniane regulacje uwzględniają element treści ekonomicznej w sposób pośredni - poprzez odniesienie do celu gospodarczego transakcji, którego wystąpienie uzasadnia odstąpienie od zastosowania klauzuli. Ponadto australijska Część IV ITAA wykorzystuje odwołanie do treści ekonomicznej przy definiowaniu korzyści podatkowej dla potrzeb zastosowania klauzuli.

\section{BIBLIOGRAFIA}

Alarie B., Duff D.G., The legacy of UK tax concepts in Canadian income tax law, „British Tax Review" 2008, no. 3.

Arnold B.J., Li J., Justice Bowman on Substance over Form, „Canadian Tax Journal” 2010, vol. 58.

Australian Government. The Board of Taxation. Review of the debt and equity tax rules. Discussion Paper, marzec 2014, http://taxboard.gov.au/files/2015/07/Debt_Equity_ Discussion_Paper.pdf (dostęp: 28.01.2018).

Azzi J., Spotless: A Lesson in Form and Substance but not in Substance over Form, „Revenue Law Journal" 1998, vol. 8.

Brzeziński B., Anglosaskie doktryny orzecznicze dotyczace unikania opodatkowania, Toruń 1996.

ekonomicznej praw i obowiązków wynikających z danego planu (scheme) lub planów niż tylko na podstawie formy prawnej tego planu lub planów". Zob. także T. Toryanik, The Concept of Substance in International Taxation. Australia, „International Transfer Pricing Journal" listopad-grudzień 2014, s. 439. 
Cassidy J., Peabody v FCT and Part IVA, „Revenue Law Journal” 1995, vol. 5.

Cassidy J., „To GAAR or Not to GAAR - That is the Question”: Canadian and Australian Attempts to Combat Tax Avoidance, „Ottawa Law Review” 2005, vol. 36, no. 2.

D’Ascenzo M., Part IVA: Post Spotless, „Journal of Australian Taxation”, lipiec/sierpień 1998.

Duff D.G., The Supreme Court of Canada and the General Anti-Avoidance Rule: Canada Trustco and Mathew, „Bulletin for International Taxation” 2006, vol. 60, no. 54.

Duggan A., Ziegel J.S., Girgis J., 449 - Shell Canada Limited: A New Taste of the Economic Substance over Form, „Canadian Business Law Journal” 1998, vol. 30.

Freedman J., Converging Tracks? Recent Developments in Canadian and UK Approaches to Tax Avoidance, „Canadian Tax Journal” 2005, vol. 53, no. 4.

Kujinga B., The UK general anti abuse rule: Lessons for Australia?, „eJournal of Tax Research” 2016, vol. 14, no. 3 .

Li J., „Economic Substance”: Drawing the line between legitimate tax minimization and abusive tax avoidance, „Canadian Tax Journal” 2006, vol. 54, no. 1.

Olesińska A., Klauzula ogólna przeciwko unikaniu opodatkowania, Torun 2013.

Philipps L., The Supreme Court of Canada's Tax Jurisprudence: What's wrong with the rule of law, „Canadian Bar Review” 2000, vol. 79.

Toryanik T., The Concept of Substance in International Taxation. Australia, „International Transfer Pricing Journal”, listopad-grudzień 2014.

Tretola J., Comparing the New Zealand and Australian GAAR, „Revenue Law Journal” 2017, vol. 25, no. 1.

Wilkie S.J., Canada: Substance in International Taxation, „International Transfer Pricing Journal”, wrzesień-październik 2014.

\section{THE MEANING OF THE CONCEPT OF ECONOMIC SUBSTANCE IN THE TAX SYSTEMS OF CANADA AND Australia}

Summary. The article concentrates upon the issue of economic substance and its meaning for the tax system. In particular the aim of the article is to determine how the concept of economic substance is used in the tax systems of Canada and Australia. None of the abovementioned countries has adopted the judicial anti-avoidance doctrines so characteristic in particular for the United States. However both in Canada and in Australia the element of real economic substance of the taxpayers' activities is considered indirectly, as part of the general anti-avoidance regulations.

Keywords: tax avoidance, economic substance, general anti-avoidance clause 